\title{
B-Cell Lymphoma With Rapidly Decreasing High-Density Lipoprotein Cholesterol: A Case Report
}

\author{
Gul Sagun ${ }^{\mathrm{a}}$, Seyma Ozkanli ${ }^{\mathrm{b}, \mathrm{c}}$, Ozge Faydaliel ${ }^{\mathrm{a}}$, Ebru Zemheri ${ }^{\mathrm{b}}$, Aytekin Oguz $^{\mathrm{a}}$
}

\begin{abstract}
Low HDL-C is a rare accompanying event in patients with lymphoma with an unknown mechanism. Lipoprotein abnormalities can be considered as biological markers to follow up the malignancies and inflammatory processes as well as death resulted from these causes. We present our 76-year-old female patient who presented with fatigue and bicytopenia and subsequently developed low HDL-C at the course of diagnosis of B cell lymphoma. To our knowledge, this is the first case with rapidly decreasing HDL-C during the followup and the diagnosis of B cell lymphoma.
\end{abstract}

Keywords: B cell lymphoma; Hypocholestrolemia; Hypokalemia

\section{Introduction}

Various plasma lipid and lipoprotein changes have been identified in many inflammatory diseases and malignancies. A research has shown that high-density lipoprotein cholesterol (HDL-C), low-density lipoprotein cholesterol (LDL-C), and total cholesterol are significantly lower than normal in acute leukemia patients [1]. In particularly, hypertriglyceridemia and low HDL-C levels have been observed in children with different hematological malignancies [2]. A large B-cell lymphoma case was reported with slowly decreasing HDL-C [3]. However, to our knowledge, there are no data concerning rapidly decreasing HDL-C related to B-cell lymphoma. In this paper, we report on a patient who was referred to Istanbul Medeniyet University Goztepe Training and Research

\footnotetext{
Manuscript accepted for publication October 2, 2013

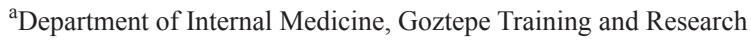
Hospital, Istanbul Medeniyet University, Istanbul, Turkey

${ }^{\mathrm{b}}$ Department of Pathology, Goztepe Training and Research Hospital, Istanbul Medeniyet University, Istanbul, Turkey

${ }^{\mathrm{c} C o r r e s p o n d i n g ~ a u t h o r: ~ S e y m a ~ O z k a n l i, ~ T u t u n c u ~ M e h m e t ~ E f e n d i ~}$ Caddesi, Karanfil Sokak, Ugur Apt. No:16/3 Goztepe-Istanbul,

Turkiye. Email: seymaozkanli@gmail.com

doi: http://dx.doi.org/10.4021/jmc1525w
}

Hospital with bicytopenia (anemia and thrombocytopenia) and hypokalemia. The patient was found to have a very low HDL-C level as a possible result of B-cell lymphoma of the bone marrow.

\section{Case Report}

A 76-year-old female with bicytopenia and hypokalemia was referred to Istanbul Medeniyet University Goztepe Training and Research Hospital Outpatient Clinic from a state hospital. The patient had been well until one month before the admission, when fatigue developed. The vital signs were reportedly normal. The patient's blood tests were normal except hypokalemia and moderate hypertrigliyceridemia. On admission to our hospital, systemic findings from a physical examination were normal; with no lymphadenopathy or organomegaly. The BMI was $22 \mathrm{~kg} / \mathrm{m}^{2}$, and the blood pressure was $130 / 80 \mathrm{mmHg}$. However, at one-month follow-up, the HDL-C had decreased rapidly, and fatigue persisted. The results of pre-and post-admission laboratory tests and laboratory data are shown in Table 1 and Table 2. Familial causes of very low HDL-C like Tangier disease were ruled out due to the patient's normal plasma lipid levels before the admission and findings of normal tonsils, a normal electromyelogram, and no corneal clouding. Ultrasonography of the abdomen revealed minimal splenomegaly (craniocaudal diameter: 121 $\mathrm{mm}$ ). Normal gastroscopic findings were present on gastroscopy. Poliposis coli was observed on colonoscopy, and a low grade dysplasia adenomatous tubulovillous adenoma was diagnosed with pathology specimens of polyps. Hypokalemia associated with the villous adenoma resulted in the loss of potassium from the lower gastrointestinal tract. Parenteral potassium replacement, about 40 meq daily, was administered until the excision of the colon polyps. Thereafter, the requirement for potassium replacement ceased.

While distinguishing the etiology of bicytopenia, the patient's body temperature increased gradually up to 38.5 ${ }^{\circ} \mathrm{C}$. Urine and blood cultures revealed negative results. The erythrocyte sedimentation rate was $61 \mathrm{~mm} / \mathrm{hr}$, and the Creactive protein was $9.34 \mathrm{mg} / \mathrm{dL}(0$ - 0.8). The Rose Bengal test, Brucella tube agglutination test, and the Gruber-Widal 
Table 1. Pre- and Post-Admission Results of Whole Blood Count, Lipid Profile and Potassium

\begin{tabular}{lll} 
Date & Pre- admission laboratory tests & Post-admission laboratory tests \\
\hline $\mathrm{Hb}(\mathrm{g} / \mathrm{dL})$ & 13.1 & 8.6 \\
$\mathrm{WBC}\left(10^{3} / \mathrm{mm}^{3}\right)$ & 6.2 & 7.2 \\
PLT $\left(10^{3} / \mathrm{mm}^{3}\right)$ & 246 & 59 \\
Total cholesterol $(\mathrm{mg} / \mathrm{dL})$ & 154 & 80 \\
LDL-C $(\mathrm{mg} / \mathrm{dL})$ & 109 & 58 \\
HDL-C $(\mathrm{mg} / \mathrm{dL})$ & 45 & 10 \\
Triglycerides $(\mathrm{mg} / \mathrm{dL})$ & 265 & 334 \\
Potassium $(\mathrm{mEq} / \mathrm{L})$ & 2.9 & 2.8 \\
\hline
\end{tabular}

LDL-C: low density lipoprotein cholesterol; HDL-C: high density lipoprotein cholesterol.

test were negative. Anti-cytomegalovirus IGG was positive, and anti-cytomegalovirus IGM and Ebstein-Barr virus
VCA were negative. A review of the peripheral blood smear revealed a population of progenitors, a small increase in

Table 2. Biochemical, Hormonal, Serological, Haematological, Urine and Arterial Blood Gas Analysis Results

\begin{tabular}{|c|c|}
\hline Glucose: $99 \mathrm{mg} / \mathrm{dL}$ & Thyroid stimulating hormone: $1.82 \mu \mathrm{IU} / \mathrm{mL}$ (normal range 0.27 - 4.2) \\
\hline Urea: $30 \mathrm{mg} / \mathrm{dL}$ & Free T3: $2.22 \mathrm{pg} / \mathrm{mL}$ (normal range 2.5 - 3.9) \\
\hline Creatinine: $0.79 \mathrm{mg} / \mathrm{dL}$ & Free T4: $0.96 \mathrm{ng} / \mathrm{dL}$ (normal range $0.61-1.12$ ) \\
\hline Sodium: $140 \mathrm{mEq} / \mathrm{L}$ & Kortizol: $17.5 \mu \mathrm{g} / \mathrm{dL}$ \\
\hline Chloride: $108 \mathrm{mEq} / \mathrm{L}$ & Protrombin time: $13.6 \mathrm{~s}$ \\
\hline Calcium: $7.58 \mathrm{mg} / \mathrm{dL}$ & INR: 1.19 \\
\hline Magnesium: $1.77 \mathrm{mg} / \mathrm{dL}$ & Activated partial thromboplastine time: $26.4 \mathrm{~s}$ \\
\hline Creatine kinase: $17 \mathrm{U} / \mathrm{L}$ & Direct Cooms: (-) negative \\
\hline Aspartate aminotransferase : $26 \mathrm{U} / \mathrm{L}$ & Indirect Cooms: (-) negative \\
\hline Alanine aminotransferase: $17 \mathrm{U} / \mathrm{L}$ & Reticulocyte: 2.26 \\
\hline LDH: $537 \mathrm{U} / \mathrm{L}$ & Anti HCV: (-) negative \\
\hline Total protein: $6.13 \mathrm{~g} / \mathrm{dL}$ & HBs Ag: (-) negative \\
\hline Albumin: $2.97 \mathrm{~g} / \mathrm{dL}$ & Anti HIV: (-) negative \\
\hline Fe: $12 \mu \mathrm{g} / \mathrm{dL}$ & Arterial blood gas analysis: \\
\hline TIBC: $225 \mu \mathrm{g} / \mathrm{L}$ & $\mathrm{pH} 7.47$ \\
\hline Ferritin: $694.8 \mathrm{ng} / \mathrm{mL}$ & HCO3: 29.3 \\
\hline Folat: $6.16 \mathrm{ng} / \mathrm{mL}$ & Urine protein: $0.26 \mathrm{~g} / 24 \mathrm{hr}$ \\
\hline Vitamin B12: $390 \mathrm{pg} / \mathrm{mL}$ & Urine potassium: $18.47 \mathrm{mEq} / 24 \mathrm{hr}$ \\
\hline
\end{tabular}




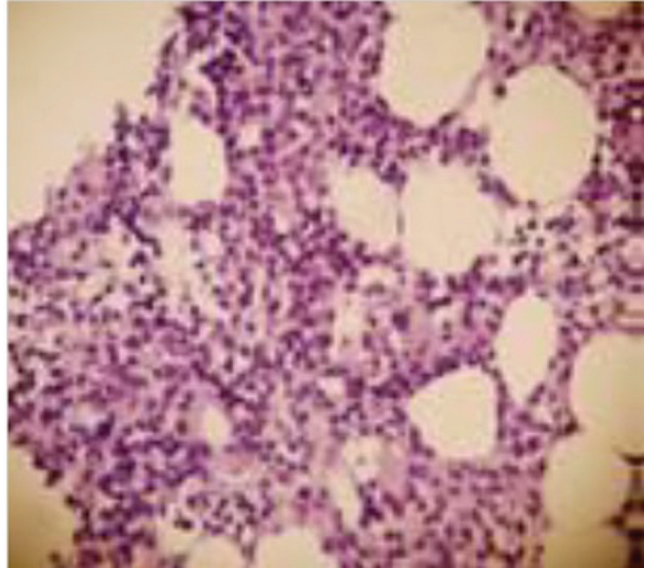

Figure 1. The core biopsy specimen of the bone marrow showing small aggregates and interstitially located atypical lymphoid cell infiltration $(H \& E \times 4)$.

atypical mononuclear cells, and increased monocytes. In the meantime, the patient's fever declined and red cell indexes returned to normal ranges with multiple blood transfusions. The patient was discharged on the tenth day pending outpatient evaluation of the results of a core biopsy specimen of the bone marrow.

Unfortunately, the patient died prior to this evaluation. The core biopsy specimen of the bone marrow revealed small aggregates and interstitially located atypical lymphoid cell infiltration with expression of CD20 (Fig. 1, 2).

\section{Discussion}

In the literature, this is the first case of a patient with an acute, severe decrease in HDL-C level associated with B-

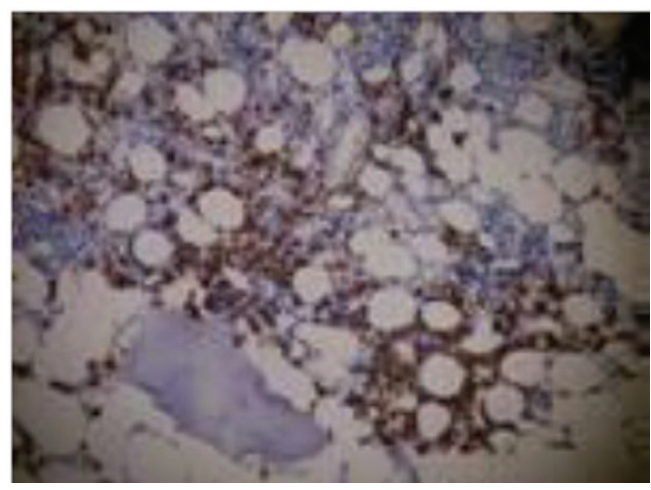

Figure 2. Immunhistochemical stained CD20 positive cells.

cell lymphoma. Decreases in total cholesterol and in LDL-C were also observed. Among the lipid parameters, the levels of triglycerides slightly increased. The disorders associated with low HDL-C levels are shown in Table 3. Tangier disease, which can be responsible for very low HDL-C levels, was ruled out due to normal plasma lipid levels before the admission and findings of normal tonsils, a normal electromyelogram, and no corneal clouding. Other familial disorders were generally related to premature atherosclerosis. However, this patient was 76 years old and had not been diagnosed with cardiovascular disease. Low plasma lipid levels combined with fever, fatigue, and bicytopenia can be related to hematological malignancies. A core biopsy of the bone morrow was performed for the differential diagnosis of bicytopenia. It revealed CD20-positive B-cell aggregates indicative of a B-cell lymphoma. Garg et al reported a 71-year-old female with decreasing HDL-C for years before a diagnosis of a large B-cell lymphoma [3]. Low circulating levels of HDL-C in lymphoma patients may occur years before the clinical presentation of cancer. They are a marker

Table 3. Etiology of Low HDL

\author{
Familial hypoalphalipoproteinemia \\ Tangier disease \\ Familial combined hypolipidemia \\ Elevated CETP activity \\ Lipoprotein lipase deficiency \\ Elevated hepatic triglyceride lipase activity \\ LCAT deficiency \\ Insulin resistance \\ Drugs \\ Others
}


for inflammation-induced lymphomagenesis, rather than a result of the lymphoma-induced acute-phase response [4]. In an in vitro study, Pugliese et al reported that neoplastic cellular growth of lymphoma cells was associated with a low cholesterol level of culture medium and that the biological role of low plasma cholesterol levels is poorly understood [5]. In contrast, our patient had no history of any hematological disease and no significant deterioration in the lipid profile before admission to the hospital.

\section{Conclusion}

Bicytopenia with a rapid and severe decrease in low plasma cholesterol levels should alert clinicians to the possibility of hematological malignancies. Hypocholestrolemia can be considered as one of the predictors of a poor prognosis, even death, in patients with neoplastic disorders.

\section{Conflict of Interest}

We, as the authors of the case report titled "B-cell lymphoma with rapidly decreasing high-density lipoprotein cholesterol" declare that there is no conflict of interests regarding the publication of this article and that we do not have a direct financial or personal relation with any people or organiza- tions.

\section{References}

1. Goncalves RP, Rodrigues DG, Maranhao RC. Uptake of high density lipoprotein (HDL) cholesteryl esters by human acute leukemia cells. Leuk Res. 2005;29(8):955959.

2. Dessi S, Batetta B, Spano O, Sanna F, Tonello M, Giacchino M, Tessitore L, et al. Clinical remission is associated with restoration of normal high-density lipoprotein cholesterol levels in children with malignancies. Clin Sci (Lond). 1995;89(5):505-510.

3. Garg A, Hosfield EM, Brickner L. Disseminated intravascular large B cell lymphoma with slowly decreasing high-density lipoprotein cholesterol. South Med J. 2011;104(1):53-56.

4. Blackman JD, Cabana VG, Mazzone T. The acute-phase response and associated lipoprotein abnormalities accompanying lymphoma. J Intern Med. 1993;233(2):201204.

5. Pugliese L, Bernardini I, Pacifico N, Peverini M, Damaskopoulou E, Cataldi S, Albi E. Severe hypocholesterolaemia is often neglected in haematological malignancies. Eur J Cancer. 2010;46(9):1735-1743. 